Research Article

\title{
Evaluation of effect of aqueous extract of leaves of Calotropis procera in pentylenetetrazole induced seizures in rats
}

\author{
Vagdevi Hangarakatte Ramachandra, Smita Shenoy*, Megha Madhyastha, Rajappayya Desai, \\ Sukanya Ghosh
}

Department of Pharmacology, Kasturba Medical College, Manipal, Karnataka, India

Received: 16 May 2016

Accepted: 21 May 2016

*Correspondence to:

Dr. Smita Shenoy,

Email: smita.shenoy

@ manipal.edu

Copyright: (C) the author(s), publisher and licensee Medip Academy. This is an openaccess article distributed under the terms of the Creative Commons Attribution NonCommercial License, which permits unrestricted noncommercial use, distribution, and reproduction in any medium, provided the original work is properly cited.

\begin{abstract}
Background: The study was carried out to evaluate the effect of aqueous extract of leaves of Calotropis procera in wistar rats.

Methods: An aqueous extract of leaves of Calotropis procera was prepared. The effect of acute and chronic administration of the extract was tested in pentylenetetrazole (PTZ) induced seizures in wistar rats. Four groups, each containing 6 rats, were used to evaluate acute and chronic effects of the extract. The four groups were treated with distilled water $10 \mathrm{~mL} / \mathrm{kg}$ (control group), Valproic acid $200 \mathrm{mg} / \mathrm{kg}$ (standard), aqueous extract of C. procera $250 \mathrm{mg} / \mathrm{kg}$ and $500 \mathrm{mg} / \mathrm{kg}$ respectively. In acute study, PTZ (60 mg/kg, intraperitoneally) was given $1 \mathrm{~h}$ after drugs were administered. In chronic study, all drugs were given for 6 weeks following which PTZ was given $1 \mathrm{~h}$ after last dose of each drug. The time taken for the onset of myoclonic jerk, seizures and duration of seizures was recorded. GABA levels were estimated in the brain homogenate. Data was analysed by one way analysis of variance followed by Tukey's test.

Results: Acute and chronic administration of the extract significantly increased the time to onset of first clonus and seizures and decreased the total duration of seizures. There was no significant change in GABA levels.

Conclusions: Both acute and chronic administration of aqueous extract of leaves of Calotropis procera in Wistar rats inhibited pentylenetetrazole induced seizures in rats.
\end{abstract}

Keywords: Calotropis procera, Seizures, Clonus, Valproic acid, Anticonvulsant

\section{INTRODUCTION}

Calotropis procera Linn.is a plant with important medicinal properties and is used in Ayurveda. Whole plant is used to treat fever, eczema, diarrohea, boils and jaundice. In addition, leaves, fresh or dried, stem, flowers, roots and root bark are also commonly used. The root has been used for the treatment of eczema, leprosy, elephantiasis, rheumatism, epilepsy and diarrhoea. The stem is used for the treatment of skin diseases, worms, leprosy and leukoderma. The latex and leaves are used to reduce pain and swelling of joints. Flowers have been found to be useful in cough and anorexia. ${ }^{1-7}$
Previous preclinical studies revealed the medicinal properties of this plant. The leaves have shown antifungal, antimicrobial, cytotoxic and anthelmintic activities. ${ }^{8-10}$ Antioxidant activity of the plant has been demonstrated. ${ }^{11}$ The stem bark has anti-inflammatory and gastroprotective effects. ${ }^{12}$ The latex exerts antinociceptive, antipyretic and antidiarrheal effects. ${ }^{13-15}$ The root extracts of Calotropis procera exerted antihyperglycemic and hypolipidemic activities in streptozotocin induced diabetic rats. ${ }^{16}$ It also has antiinflammatory and anticonvulsant actions. ${ }^{17,18}$ The root extract inhibited both pentylenetetrazole and maximal electroshock seizures. Hepatoprotective effect has been exhibited by flowers. ${ }^{19}$ 
Saponins are considered to have potential for anticonvulsant actions. $^{20}$ Saponin containing plant extracts have inhibited pentylenetetrazole induced seizures. ${ }^{21}$ Phytochemical analysis of water extract of leaves of this plant has shown presence of saponins. ${ }^{22}$ Hence, the aim of this study was to evaluate anticonvulsant property of aqueous extract of leaves of Calotropis procera in pentylenetetrazole induced seizures in rats.

\section{METHODS}

The study was carried out after obtaining clearance from Institutional Animal Ethics Committee, Manipal.

\section{Drugs and chemicals}

Pentylenetetrazole (PTZ; Sigma, USA) and valproic acid (Sun pharma, Mumbai) were used in this study. Analytical grade chemicals were used in the study.

\section{Preparation of extract}

The leaves of Calotropis procera were procured from a local ayurvedic shop in Udupi. The leaves were authenticated by a botanist. They were shade dried and coarsely ground with a grinder. The coarse powder was immersed in distilled water in a flask for seven days. This was filtered using Whatman filter paper. The filtrate was concentrated on water bath to get a viscous paste. It was finally dried in a desiccator.

\section{Animals}

Adult, male Wistar rats weighing 150-200 g were used in the study. They were housed individually in cages, at a temperature of $27 \pm 3^{\circ} \mathrm{C}$, relative humidity of $60 \pm 10 \%$ and $12 \mathrm{~h}$ light/dark cycle. Animals were maintained on standard diet food and water ad libitum.

\section{Procedure}

Pentylenetetrazole (PTZ) induced seizures model was used to evaluate anticonvulsant action of aqueous extract of Calotropis procera. The acute and chronic effect of the extract on PTZ induced seizures was assessed. A total of 48 rats were used for the study-they were randomly allotted for acute and chronic study. For each study, 24 rats were used.

\section{Acute study}

Four groups of rats with 6 animals in each were administered drugs as follows;

Group I (Control): distilled water $(10 \mathrm{~mL} / \mathrm{kg})$

Group II (Standard): Valproic acid (200 mg/kg)

Group III (Test): Aqueous extract of $C$. procera (250 mg/kg)

Group IV (Test): Aqueous extract of $C$ procera-500 $\mathrm{mg} / \mathrm{kg}$
All drugs were administered 1 hour prior to administration of PTZ (60 mg/kg, i.p.). ${ }^{23}$ The dose of the plant extract was calculated from earlier acute toxicity studies. ${ }^{24}$ Drugs were administered orally. Each animal was placed in an individual cage for observation lasting $30 \mathrm{~min}$. The time taken for the onset of myoclonic jerk, seizures and duration of seizures was recorded. ${ }^{23,25}$

\section{Chronic study}

Four groups of rats with 6 animals in each were used. All drugs (as mentioned in acute study) were administered once a day between 15:00 and 17:00 hours for 6 weeks prior to the administration of PTZ $(60 \mathrm{mg} / \mathrm{kg}$, i.p.) which was administered $1 \mathrm{~h}$ after last dose of test drug. ${ }^{26}$ Each animal was placed in an individual cage for observation lasting $30 \mathrm{~min}$. The parameters recorded was same as that of acute study.

\section{Estimation of GABA in the brain}

Rats were sacrificed, brain dissected out and homogenized in phosphate buffer. GABA was estimated by simple spectroscopic method. ${ }^{27}$

\section{Statistical analysis}

The data was expressed as mean \pm SEM. The data was analysed by one way analysis of variance (ANOVA) followed by Tukey's test. A p-value $<0.05$ was considered statistically significant.

\section{RESULTS}

\section{Acute study}

Aqueous extract of leaves of Calotropis procera in both doses produced anticonvulsant effect in PTZ induced seizures. The time to onset of first clonus and seizures was significantly increased. The total duration of seizures was significantly decreased (Table 1). There was no significant change in GABA levels (Table 2).

Table 1: Effect of acute administration of aqueous extract of leaves of Calotropis procera on PTZ induced seizures in rats.

\begin{tabular}{|llll|}
\hline Groups & $\begin{array}{l}\text { Latency of } \\
\text { first clonus }\end{array}$ & $\begin{array}{l}\text { Latency of } \\
\text { seizures } \\
\text { (Seconds) Mean } \pm \text { SEM }\end{array}$ \\
\hline 1 & \multicolumn{4}{c|}{$\begin{array}{l}\text { Total } \\
\text { duration of } \\
\text { convulsions }\end{array}$} \\
\hline 2 & $134.33 \pm 1.58$ & $70.66 \pm 1.28$ & $151 \pm 9.86$ \\
\hline 3 & $138.8 \pm 8.78^{*}$ & $195.8 \pm 59.99 *$ & $89.1 \pm 14.6 * *$ \\
\hline 4 & $120.6 \pm 4.63 * *$ & $154.6 \pm 10.58^{*}$ & $96.83 \pm 3.59 * *$ \\
\hline$*_{\mathrm{p}<0.001}$ vs control; $* * \mathrm{p}<0.034$ vs control; & ANOVA followed \\
\hline
\end{tabular}
by Tukey's test. 
Table 2: Effect of acute administration of aqueous extract of leaves of Calotropis procera on levels of

GABA in the brain.

\begin{tabular}{|ll|}
\hline Groups & GABA in $\mu \mathrm{mol} / \mathrm{g}($ Mean \pm SEM $)$ \\
\hline 1 & $90.7 \pm 9.90$ \\
\hline 2 & $120.8 \pm 18.57$ \\
\hline 3 & $106.05 \pm 8.63$ \\
\hline 4 & $95.5 \pm 10.10$ \\
\hline
\end{tabular}

ANOVA followed by Tukey's test.

\section{Chronic study}

Chronic administration of the extract significantly protected against PTZ induced seizures (Table 3). There was no significant difference between the effects produced by the extract and valproate. There was no significant alteration in GABA levels (Table 4).

Table 3: Effect of chronic administration of aqueous extract of leaves of Calotropis procera on PTZ induced seizures in rats.

\begin{tabular}{|llll|}
\hline Groups & $\begin{array}{l}\text { Latency of } \\
\text { first clonus }\end{array}$ & $\begin{array}{l}\text { Latency of } \\
\text { seizures } \\
\text { (Seconds) Mean } \pm \text { SEM }\end{array}$ & $\begin{array}{l}\text { Total } \\
\text { duration of } \\
\text { convulsions }\end{array}$ \\
\hline 1 & $52.16 \pm 3.94$ & $59.66 \pm 3.79$ & $151 \pm 9.86$ \\
\hline 2 & $166.3 \pm 19.11^{*}$ & $278.21 \pm 70.12^{*}$ & $60 \pm 6.49^{*}$ \\
\hline 3 & $158.3 \pm 65.51^{*}$ & $194.86 \pm 129.7 *$ & $91.3 \pm 25.55^{* *}$ \\
\hline 4 & $163.6 \pm 47.76^{*}$ & $200.63 \pm 145.4^{*}$ & $86.6 \pm 15.77^{* *}$ \\
\hline
\end{tabular}

$* \mathrm{p} \leq 0.001$ vs control; $* * \mathrm{p} \leq 0.05$ vs control; ANOVA followed by Tukey's test.

Table 4: Effect of chronic administration of aqueous extract of leaves of Calotropis procera on levels of GABA in the brain.

\begin{tabular}{|ll|}
\hline Groups & GABA in $\mu \mathrm{mol} / \mathrm{g}(\mathrm{Mean} \pm \mathrm{SEM})$ \\
\hline 1 & $117.3 \pm 11.42$ \\
\hline 2 & $135.5 \pm 23.35$ \\
\hline 3 & $113.5 \pm 8.39$ \\
\hline 4 & $115 \pm 10.27$ \\
\hline
\end{tabular}

ANOVA followed by Tukey's test.

\section{DISCUSSION}

Despite availability of new drugs in modern medicine, some cases of epilepsy are refractory to treatment. In addition, side effects of these drugs affect patient compliance. This has led to search for treatment from alternate system of medicine.

Pentylenetetrazole (PTZ), a tetrazol derivative, is commonly used as a chemoconvulsant to screen antiepileptic drugs. ${ }^{28}$ It can produce myoclonic jerk which can become generalized tonic clonic seizures. Drugs which suppress PTZ induced seizures are potentially useful in absence seizures. In this study, aqueous extract of leaves of Calotropis procera produced anticonvulsant effect which was evident by the significant delay in the onset of myoclonic jerk and clonic convulsions and reduced duration of seizures. The effect was observed following both acute and chronic administration of the plant extract.

The mechanism of anticonvulsant action of pentylenetetrazole is not clearly known. It probably acts on GABA receptor and blocks the picrotoxin sensitive site. ${ }^{29}$ It blocks GABA transmission in the brain. ${ }^{30} \mathrm{GABA}$ is an inhibitory neurotransmitter in the CNS. It binds to its receptor, causes influx of chloride ion, resulting in hyperpolarization of neuronal membranes. Disturbance in GABAergic transmission plays a role in epilepsy. It has been shown that drugs enhancing GABA transmission can prevent seizures induced by pentylenetetrazole. ${ }^{31}$ PTZ can also activate glutamate receptors (NMDA) to produce seizures. ${ }^{32}$ Seizures induced by PTZ can also be blocked by reducing T-type $\mathrm{Ca}^{2+}$ currents. ${ }^{33}$ Valproic acid inhibits PTZ induced seizures. It increases GABA levels by promoting its synthesis and decreasing degradation. It also blocks calcium mediated $\mathrm{T}$ current. ${ }^{34}$ The extract of Calotropis procera leaves did not show significant increase in GABA levels in the brain homogenate. So, it could have acted directly on GABA receptor to enhance neurotransmission or it could have blocked T-currents or interfered with glutaminergic transmission.

Phytochemical analysis of leaf of Calotropis procera in previous studies have shown the presence of tannins, glycosides, phenols, terpenoids, alkaloids and saponins. ${ }^{22}$ Saponin containing plant extracts have shown potential in the treatment of convulsions. ${ }^{35}$ Terpenoids isolated from plants have inhibited seizures in animal models. ${ }^{36}$ These phyto-constituents could have contributed to the anticonvulsant effect of leaves of Calotropis procera.

\section{CONCLUSION}

Aqueous extract of leaves of Calotropis procera produced anticonvulsant effect against pentylenetetrazole induced seizures. Future direction involves studies to standardize it and elucidate its exact mechanism of action.

\section{Funding: No funding sources}

Conflict of interest: None declared

Ethical approval: The study was approved by the Institutional Ethics Committee

\section{REFERENCES}

1. Chatterjee A, Prakash SC: In: The Treatise of Indian Medicinal Plants. New Delhi, Publications and Information Directorate;1994:130-131.

2. Nadakarni KM: In: Indian Materia Medica. Popular Prakashan, Mumbai, India;2002:242-247.

3. Alikhan I, Khanum A. Medicinal and aromatic plants of India. Ukaaz Publication, India;2005:33-4.

4. Abhishek D, Mohit C, Ashish G, Ameeta A. medicinal utility of Calotropis procera r. br. as used by natives of village Sanwer of Indore District, Madhya Pradesh. Intern J Pharm Life Sci. 2010;1(3):188-90. 
5. Khairnar AK, Bhamare SR, Bhamare HP. Calotropis procera: An ethno pharmacological update. Advance Res Pharm Biolog. 2012;2(2):142-56.

6. Al-Snafi AE. The constituents and pharmacological properties of Calotropis procera: an overview. Int $\mathrm{J}$ Pharm Pharm Res. 2015;3:259-75.

7. Meena AK, Yadav A, Rao MM. Ayurvedic uses and pharmacological activities of Calotropis procera Linn. Asian J Tradit Med. 2011;6(2):45-53.

8. Halu B, Vidyasagar GM. A comparative study: differential antimycoses activity of crude leaf extracts of Calotropis Spp. Int J Pharm Pharm Sci. 2012;4(3):705-8.

9. Mako GA, Memon AH, Mughal UR, Pirzado AJ, Bhatti SA. Antibacterial effects of leaves and root extract of Calotropis procera Linn. Pak J Agri Agril Engg Vet Sci. 2012;28(2):141-9.

10. Murti Y, Singh A, Pathak D. In vitro anthelmintic and cytotoxic potential of different extracts of Calotropis procera leaves. Asian J Pharm Clin Res. 2013;6(1):145 .

11. Yesmin MN, Uddin SN, Mubassara S, Akond MA. Antioxidant and antibacterial activities of Calotropis procera Linn. American-Eurasian J Agric \& Environ Sci. 2008;4(5):550-3.

12. Tour N, Talele G. Anti-inflammatory and gastromucosal protective effects of Calotropis procera (Asclepiadaceae) stem bark. J Nat Med. 2011;65(34):598-605.

13. Dewan S, Kumar S, Kumar VL. Antipyretic effect of latex of Calotropis procera. Indian $\mathrm{J}$ Phar. 2000;32:252.

14. Kumar VL, Sangraula H, Dewan S. Preliminary studies on the analgesic activity of latex of Calotropris procera.. J Ethnopharmacol. 2000;73(1-2):307-11.

15. Kumar VL, Sangraula H, Dewan S, Kumar S. Antidiarrheal activity of the latex of Calotropis procera. J Ethnopharmacol. 2001;76(1):115-8.

16. Bhaskar VH, Ajay SS. Antihyperglycemic and antihyperlipidaemic activities of root extracts of Calotropis procera(Ait.) R.Br on streptozotocin induced diabetic rats. Jordan J Biol Sci. 2009;2(4):17780.

17. Suresh BAR, Karki SS. Anti-inflammatory activity of various extracts of roots of Calotropis procera against different inflammation models. Int J Pharm Pharm Sci. 2011;3(3):191-4.

18. Jalalpure SS. Anticonvulsant effects of Calotropis procera root in rats. Pharm Biol. 2009;47(2):162-7.

19. Setty RS, Absar QA, Swamy VAHM, Patil T, Prakash T, Prabhu K, Gouda V. Hepatoprotective activity of Calotropis procera flowers against paracetamolinduced hepatic injury in rats. Fitoterapia. 2007;78(1):451-4.

20. Hui LZ, Wan JB, Wang YT, Li BC, Xiang C, He J, et al. Medicinal compounds with antiepileptic/anticonvulsant activities. Epilepsia. 2014;55(1):3-16.

21. Chindo BA, Anuka JA, McNeil L, Yaro AH, Adamu SS, Amos S, et al. Anticonvulsant properties of saponins from Ficus platyphylla stem bark. Brain Res Bull. 2009;78:276-82.
22. Murti Y, Yogi B, Pathak D. Pharmacognostic standardization of leaves of Calotropis procera(Ait.) R. Br. (Asclepiadaceae). Int J Ayurveda Res. 2010;1(1):14-17.

23. Snehunsu A, Mukunda N, Satish KMC, Sadhana N, Sareesh NN, Kapgal VK, et al. Evaluation of antiepileptic property of Marsilea quadrifolia Linn. in maximal electroshock and pentylenetetrazole-induced rat models of epilepsy. Brain Inj. 2013;27(1314):1707-14.

24. Mohammed A, Ibrahim S, Bilbis LS. Toxicological investigation of aqueous leaf extract of Calotropis procera(Ait.) R.Br.in Wistar albino rats. Afr J Biochem Res. 2012;6(7):90-7.

25. Sudha, S, Kumaresan S, Amit A, David J, Venkataraman BV. Anticonvulsant activity of different extracts of Centella asiatica and Bacopa monnieri in animals. J Nat Remed. 2002;2:33-41.

26. Kumar S, Megha M, Chogtu B, Bairy KL. Effect of acute and chronic administration of losartan, atorvastatin and their combination on animal models of epilepsy. Res J Pharm, Bio Chem Sci. 2015;6(4):1795801.

27. Habibur R, Eswaraiah MC. Simple spectroscopic methods for estimating brain neurotransmitters, antioxidants enzymes of laboratory animals like mice: a review. Pharmatutor Art. 2008;1244.

28. Hosseinzadeh H, SadeghniaHR. Protective effect of safranal on pentylenetetrazol-induced seizures in therat: involvement of GABAergic and opioids systems. Phytomedicine. 2007;14:256-62.

29. Ramanjaneyulu R, Ticku MK. İnteractions of pentamethylenetetrazole and tetrazole analogues with the picrotoxin site of the benzodiazepine- GABA receptor-ionophore complex. Eur J Pharmacol. 1984;98:337-45.

30. Gupta G, Afzal M, David S, Verma R, Candaswamy M, Anwar F. Anticonvulsant activity of Morus alba and its effect on brain gamma-aminobutyric acid level in rats. Pharmacog Res. 2014;6:188-9.

31. MacDonald RL, Kelly KM. Anti-epileptic drug mechanisms of action. Epilepsia. 1995;36:2-12.

32. Yudkoff M, Daikhin Y, Nissim I, Horyn O, Luhovyy B, Lazarow A, et al. Short-term fasting, seizure control and brain amino acid metabolism. Neurochem Int. 2006;48:650-6.

33. Meldrum BS. Update on the mechanism of action of antiepileptic drugs. Epilepsia. 1996;37:4-11.

34. Davis LL, Ryan W, Adinoff B, Petty F. Comprehensive review of the psychiatric uses of valproate. J Clin Psychopharmacol. 2000;20:1-17.

35. Jalsrai A, Grecksch G, Becker A. Evaluation of the effects of Astragalus mongholicus Bunge saponin extract on central nervous system functions. J Ethnopharmacol. 2010;131:544-9.

36. Taviano MF, Miceli N, Monforte MT. Ursolic acid plays a role in Nepeta sibthorpii bentham CNS depressing effects. Phytother Res. 2007;21: 382-5.

Cite this article as: Ramachandra VH, Shenoy S, Madhyastha M, Desai R, Ghosh S. Evaluation of effect of aqueous extract of leaves of Calotropis procera in pentylenetetrazole induced seizures in rats. Int J Basic Clin Pharmacol 2016;5:643-6. 